\title{
Morphological and DNA-based Classification of Cyathus sp. Isolates from Thailand (Basidiomycota, Nidulariaceae)
}

\author{
Waraporn Sutthisa ${ }^{1 *}$ (D) and Niwat Sanoamuang ${ }^{2,3}$ \\ ${ }^{1}$ Department of Biology, Faculty of Science, Mahasarakham University, Kantarawichai District, Maha Sarakham \\ Province, 44150 Thailand. ${ }^{2}$ Department of Plant Science and Agricultural Resources, Faculty of Agriculture, \\ Khon, Kaen University, Khon Kaen, 40002 Thailand. ${ }^{3}$ Applied Taxonomic Research Center, Khon Kaen University, \\ Khon Kaen, 40002 Thailand.
}

\begin{abstract}
Cyathus sp. isolates from three areas in Thailand (Khon Kaen University, Nam Nao National Park and Phu Ruea, Loei Province) were morphologically characterized by their peridiocarp, peridioles and basidiospores. This allowed to assign most isolates to five Cyathus species: $C$. berkeleyanus, $C$. earlei, C. pallidus, $C$. stercoreus and $C$. striatus. Phylogenetic analysis of ribosomal ITS sequence data yielded three groups of Cyathus isolates and unidentified species group. The Pallidum group including KKUNN1, is closely related to C. berkeleyanus (DQ463355.1), KKUITN2 (KU202745) and KKUITN3 (KU202751) are closely related to $C$. pallidus (DQ463356.1). The Ollum group includes $C$. africanus and $C$. hookeri. The Striatum group, such as KKUITP2 (KU202744) and KKUITP3 (KU202743) are closely related to $C$. stercoreus (DQ463356.1). The LSU sequence data suggest that KKULN2 and KKULN3 are closely related to C. pallidus (DQ463336.1), whereas KKULP2 and KKULP3 are closely related to C. stercoreus.

Keywords: Cyathus, ribosomal internal transcribed spacer (ITS), large subunit ribosomal DNA (LSU rDNA), peridiocarp
\end{abstract}

*Correspondence: waraporn.s@msu.ac.th

(Received: May 25, 2020; accepted: August 13, 2020)

Citation: Sutthisa W, Sanoamuang N. Morphological and DNA-based Classification of Cyathus sp. Isolates from Thailand (Basidiomycota, Nidulariaceae). J Pure Appl Microbiol. 2020;14(3):1769-1777. doi: 10.22207/JPAM.14.3.15

(C) The Author(s) 2020. Open Access. This article is distributed under the terms of the Creative Commons Attribution 4.0 International License which permits unrestricted use, sharing, distribution, and reproduction in any medium, provided you give appropriate credit to the original author(s) and the source, provide a link to the Creative Commons license, and indicate if changes were made. 


\section{INTRODUCTION}

The bird's nest fungi (phylum Basidiomycota, agaricoid clade, family Nidulariaceae) comprize five genera, viz. Crucibulum, Mycocalia, Nidularia, Nidula and Cyathus ${ }^{1-4}$. Typically, these genera produce small fruiting bodies on soil, animal droppings or organic matter ${ }^{5}$. The presence of gray to black peridioles with funicular cords distinguishes Cyathus from the other nidulariacean genera ${ }^{6}$. Cyathus species are inedible mushrooms that absorb nutrients into their cells by releasing enzymes to decompose organic matter. The basidiocarp of Cyathus sp. is funnel shaped with peridioles and a funicular cord. The basidiocarp are off-white color covered with fluffy hair and the reason that makes it different from other species because of the peridium surface is folded and contains subspherical basidiospores ${ }^{7,8}$. There are 45 species in this genus ${ }^{3}$, which have spread around the world, especially in warm and hot areas ${ }^{5}$. There are doubts about the propriety of the old classification system based on the traditional taxonomy. Basidiocarps examination presented a large amount variation between the various collections, and morphological identification. Observations show that all culture collections were classified using morphology of basidiocarp. So, Martin et al. ${ }^{9}$ collected Cyathus from Cape Verde and identified by using morphology and molecular data. They obtained a new species, Cyathus lignilantanae sp. nov. Whereas, Amazonian Cyathus species have a new species such as Cyathus albinus with light color hirsute exoperidium contrasting with a dark brown emplacement and basidiospores ovoid to elliptical and the other three such as $C$. amazonicus, $C$. earlei and $C$. triplex, are recorded for the first time from their localities ${ }^{10}$. The extinct category of the Red List of Threatened Fungi of Japan found that $C y a t h u s$ badius and $C$. boninensis are included. The last and the only collections of both species were made in 1936, and no additional samples have been collected since then. Nowadays the samples were collected and morphological comparisons with the holotype and phylogenetic analyses based on ribosomal ITS, LSU and concatenated dataset placed $C$. badius in a highly contributed clade with C. parvocinereus ${ }^{11}$. In northern Thailand, 16 species of the five nidulariacean genera have been collected ${ }^{6}$, including the new species Cyathus subglobisporus which on the basis of ITS and LSU nucleotide sequence data was assigned to the Striatum species group ${ }^{6}$. Yet, despite these few previous studies, the species diversity of the family Nidulariaceae, and of the genus Cyathus in particular, in Thailand remains poorly documented. Therefore, we report here on the identification of 12 specimens of Cyathus from NE Thailand, based on morphological data combined with ITS and LSU nucleotide sequences.

\section{MATERIALS AND METHODS}

Microorganisms and morphological identification

Twelve isolates of Cyathus sp. were collected from three parts of NE Thailand, including Khon Kaen University (KKU1, KKU2, KKU3, KKU4, KKU5, KKU6), Nam Nao National Park (KKUNN1, KKUITN2, KKUITN3) and Phu Ruea, Loei Province (KKULP1, KKUITP2, KKUITP3), all samples were sent to the Plant Pathology Laboratory, Khon Kaen University. Voucher specimens were deposited at Khon Kaen University Culture Collection (KKU). The isolates were identified using the methodologies proposed by Fungi Keys, Mushroom Expert ${ }^{2,12,13}$. Macroscopic features were described from fresh basidiocarps with a stereomicroscope (Carl Zeiss). Peridioles of the basidiospores were crosssectioned and mounted with $3 \% \mathrm{KOH}$ solution for observation under a microscope (Zeiss Primo Star) with AxioVision Rel.4.8.2. Thirty basidiospores were measured ${ }^{14,15}$.

\section{DNA analyses}

Each isolate was cultured in potato dextrose broth (PDB), shaked at $120 \mathrm{rpm}$ for 7 days. Subsequently, mycelia were collected and stored at $-20^{\circ} \mathrm{C}$ for 24 hours. Total genomic DNA was extracted following Zang ${ }^{13}$. The universal primers ITS1 (5'-TCCGTAGGTGAACCTGCGG-3') and ITS4 ( $5^{\prime}$-TCCTCCGCTTATTGATATGC- $3^{\prime}$ ) were used to amplify the ribosomal ITS region ${ }^{16}$ and NL1 (5'-GCATATCAATAAGCGGAGGAAA AG-3') and NL4 (5' GGTCCGTGTTTCAAGACGG-3') to amplify large subunit ribosomal DNA (LSU rDNA) region ${ }^{17}$. PCR reaction mixtures and running conditions were as described by Sutthisa and Sanoamuang ${ }^{18}$. PCR amplicons were examined by gel electrophoresis ${ }^{19}$ and sent to First BASE Laboratories Sdn. for sequencing. 
DNA sequence alignment and phylogenetic analysis

ClustalX2 was used to align nucleotide sequences according to its default settings ${ }^{20,21}$. Cyathus sp. comprise of 10 species for ITS, 12 species for LSU and four other bird's nest fungi obtained from GenBank (Table 1) with. PAUP v.4.0b101 were used for phylogenetic analysis following Swofford ${ }^{22}$, Felsenstein ${ }^{23}$, Huelsenbeck and Ronquist ${ }^{24}$ and Page ${ }^{25}$ methods.

\section{RESULTS}

\section{Morphological characterization}

The morphological identification of Cyathus sp. isolates was based on Fungi Keys, Mushroom Expert ${ }^{2,12,13}$. The isolates were classified as follows:

\section{Cyathus berkeleyanus (Tul. \& C. Tul.) Lloyd} Isolate KKUNN1. Peridium campanulate to infundibuliform, $11.0-13.0 \mathrm{~mm}$ high and mouth 7.0-80 $\mathrm{mm}$ wide. Exoperidium hairy, covered tomentum, pale brown to brown. Endoperidium brown with conspicuously plicate. The diameter of peridioles $1.5-2.5 \mathrm{~mm}$, with dark brown to black color, ellipsoid or lenticular in outline. Basidiospores smooth, hyaline, ellipsoid, 9.0-12.0 x 5.0-7.0 $\mu \mathrm{m}$, thin walled, 1-2.5 $\mu \mathrm{m}$ (Fig. 1).

\section{Cyathus earlei Lloyd}

Isolate KKUPR1. Peridium infundibuliform, 4.9-8.1 $\mathrm{mm}$ high, mouth 1.2-5.5 mm wide. Hairy exoperidium with brown and sable color and filled with tomentum. Endocardium brownish grey to grey, unruffle to slightly plicate. Diameter of peridioles 1.3-1.9 mm, peridioles dark grey to black, circular or lenticular in outline. Basidiospores smooth, hyaline, elliptical to ovoid, 8.6-20.1 x 7.9$11.1 \mu \mathrm{m}$, thin walled, 1.27-2.54 $\mu \mathrm{m}$ (Fig. 2).

Cyathus pallidus Berk. \& M.A.Curtis

Isolates KKUITN2 and KKUITN3. Peridium campanulate, 6.2-13.1 $\mathrm{mm}$ high, mouth 2.8-6.9 $\mathrm{mm}$ wide. Exoperidium hairy, cream to brown, covered with tomentum. Endoperidium pale brown, flat to slightly plicate, lightly bright, not differ from exterior. Peridioles 1.6-2.9 $\mathrm{mm}$ in diameter, dark grey to black, circular or lenticular in outline. Basidiospores smooth, hyaline, sub-

Table 1. All the isolates with their origin and GenBank accession numbers

\begin{tabular}{|c|c|c|c|}
\hline \multirow[t]{2}{*}{ Taxon } & \multirow[t]{2}{*}{ Origin } & \multicolumn{2}{|c|}{ GenBank accession number } \\
\hline & & ITS & LSU \\
\hline Cyathus sp. & China & KJ195660.1 & EF613554.1 \\
\hline C. africanus & China & DQ463340.1 & DQ463330.1 \\
\hline \multirow[t]{2}{*}{ C. annulatus } & USA & NR 119588.1 & - \\
\hline & Thailand & - & DQ463332.1 \\
\hline C. berkeleyanus & China & DQ463355.1 & - \\
\hline C. crassimurus & USA & NR 119587.1 & - \\
\hline C. helenae & Canada & - & DQ463334.1 \\
\hline C. jiayuguanensis & China & - & DQ463325.1 \\
\hline C. olla f. anglicus & USA & - & DQ463326.1 \\
\hline C. pallidus & China & DQ463356.1 & DQ463336.1 \\
\hline C. poeppigii & China & - & DQ463339.1 \\
\hline C. renweii & China & NR 119589.1 & DQ463333.1 \\
\hline C. setosus & Jamaica & - & DQ463331.1 \\
\hline \multirow[t]{2}{*}{ C. stercoreus } & UK & EU784193.1 & - \\
\hline & China & & DQ463338.1 \\
\hline \multirow[t]{2}{*}{ C. striatus } & USA & DQ486697.1 & - \\
\hline & Germany & & DQ071742.2 \\
\hline Crucubulum laeve & Germany & DQ071701.2 & DQ071771.1 \\
\hline Mycocalia denudata & USA & DQ911596.1 & - \\
\hline Nidula sp. & China & KC763972.1 & - \\
\hline Nidularia balachowskii & Israel & - & JX436154.1 \\
\hline Sphaerobolus sp. & USA & AY654738.1 & AY654737.1 \\
\hline
\end{tabular}


globose to elliptical, 6.8-14.5 × 6.0-8.1 $\mu \mathrm{m}$, thin walled 1-1.27 $\mu \mathrm{m}$ (Fig. 3).

Cyathus stercoreus (Schwein.) de Toni

Isolates KKUITP2 and KKUITP3. Peridium cone-shaped to goblet-like or a narrow inverted cone, 6.6-9.6 $\mathrm{mm}$ high, with mouth diameter 4.1-7.3 mm. Endoperidium yellowish brown, quite shaggy or wooly (at least when young).
Endoperidium gray to black and smooth. Peridioles 1.9-2.8 $\mathrm{mm}$ in diameter, dark gray to black, ellipsoid or lenticular in outline. Basidiospores smooth, hyaline, sub-globose to ovoid (Fig. 4).

\section{Cyathus striatus (Huds.) Willd}

Isolate KKU1, KKU2, KKU3, KKU4, KKU5 and KKU6. Peridium funnel-shaped, $8.0-10 \mathrm{~mm}$ high, mouth diameter 7.0-9.0 mm. Exoperidium

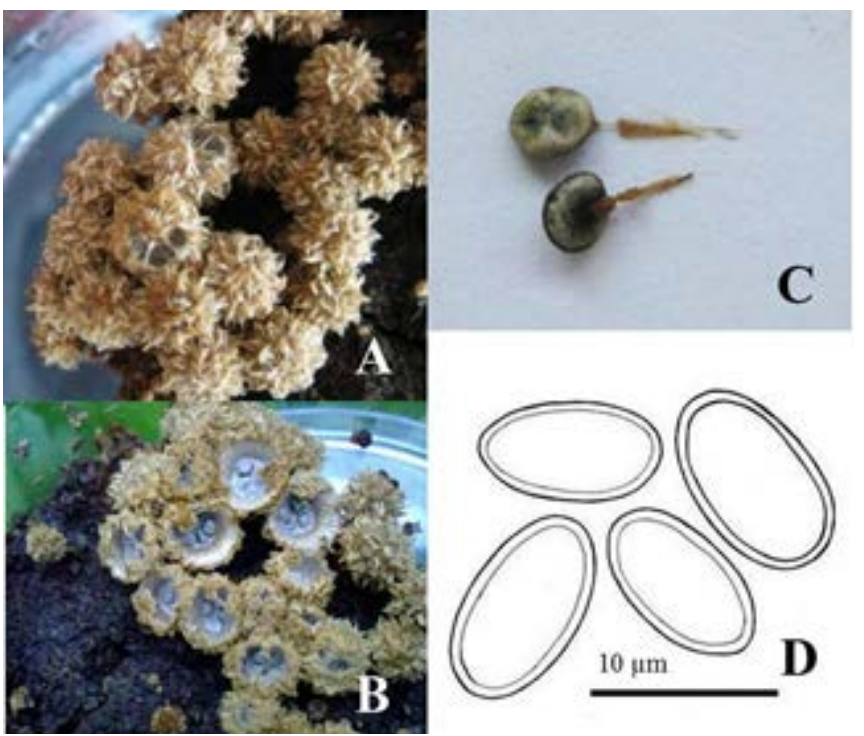

Fig. 1. Cyathus berkeleyanus KKUNN1 - A-B, Basidiocarps; C, Peridioles; D, Basidiospores.

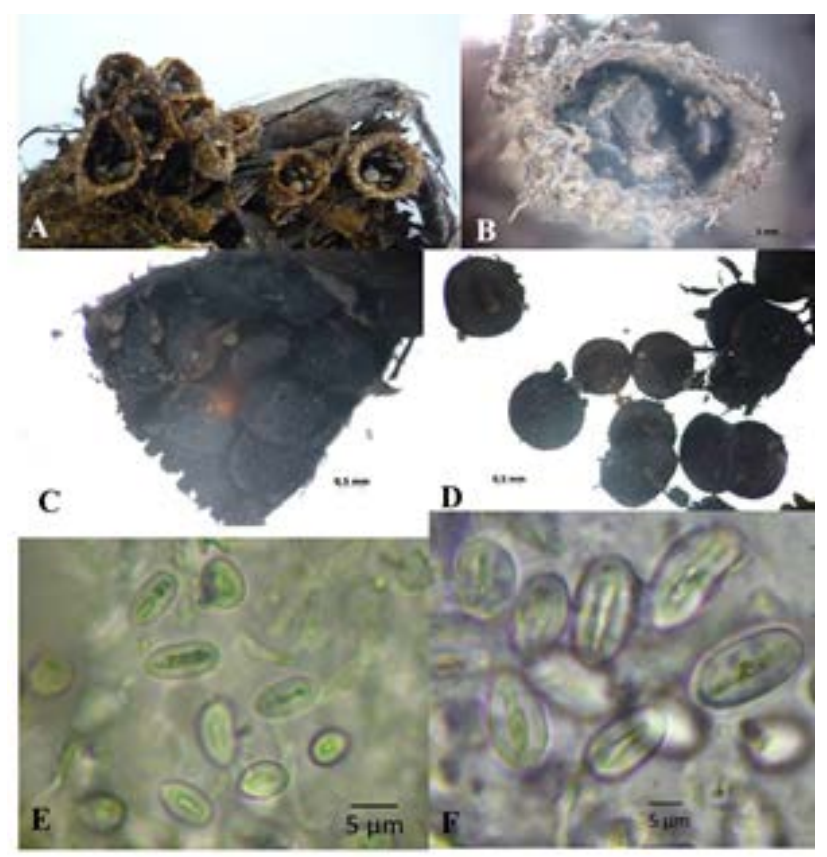

Fig. 2. Cyathus earlei KKUPR1 - A-B, Basidiocarps; C-D, Peridioles; E-F, Basidiospores.

Journal of Pure and Applied Microbiology 
shaggy to hairy, with tufts of hairs, brown to reddish brown, covered with tomentum, woolly. Endoperidium grayish brown, external wall plicate, covered with tomentum, lid typically white, disappearing with maturity. Peridiole diameter 1.5-2.5 mm, peridioles dark grey to black, ellipsoid or lenticular in outline. Basidiospores spheroidal to oval shaped, hyaline, unruffled, 16.0-20.0 × 10.0$12.0 \mu \mathrm{m}$, the wall was thick with 2-3 $\mu \mathrm{m}$ (Fig. 5).

\section{DNA sequence characterization}

The ITS dataset involved 26 isolates representing 22 Cyathus taxa, with Crucibulum leave, Mycocalia denudata, Nidula sp. and Sphaerobolus sp. as outgroup. Our phylogenetic analyses showed three groups of Cyathus isolates and an unidentified species group. The Pallidum group including KKUNN1 and is closely related to $C$. berkeleyanus (DQ463355.1), KKUITN2 and KKUITN3 are closely related to $C$. pallidus (DQ463356.1). The Ollum group includes $C$. africanus and $C$. hookeri. The Striatum group, such as KKUITP2 and KKUITP3, are closely related to C. stercoreus (DQ463356.1). Unidentified group including KKUPR1 is related closely to Cyathus sp. (KJ195660.1). However, KKU1, KKU2, KKU3, KKU4, KKU5 and KKU6 are not related to Cyathus taxa and other bird's nest fungi tested in this study (Fig. 6). The LSU dataset included 27 isolates representing 24 Cyathus taxa, with Crucibulum leave, Nidularia balachowskii and Sphaerobolus sp. as outgroup. Our phylogenetic analyses showed that KKULN2 and KKULN3 are closely related to $C$. pallidus

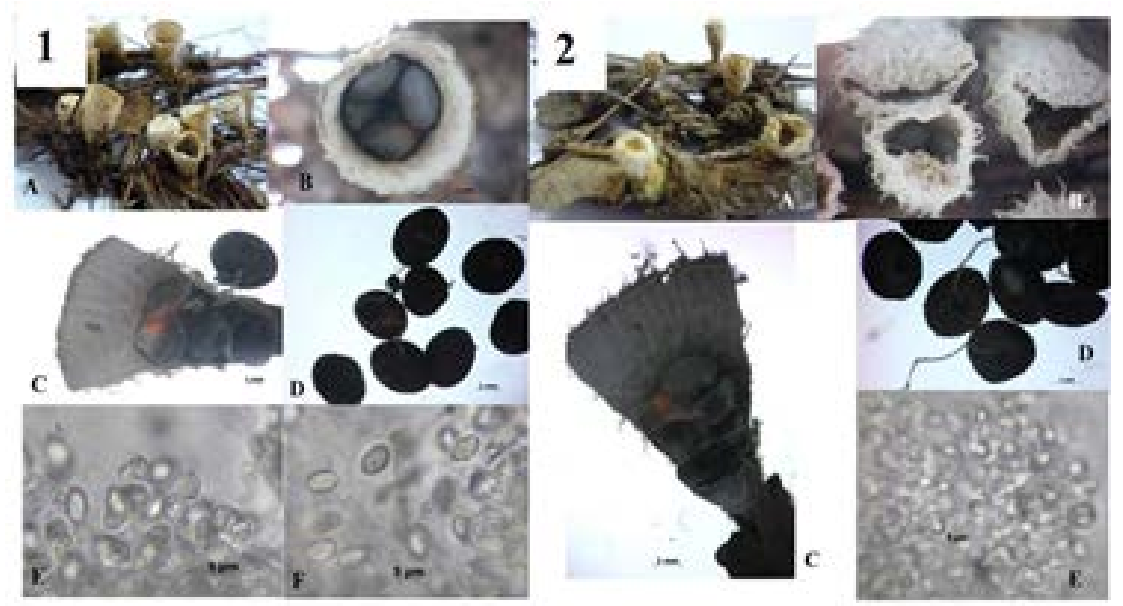

Fig. 3. Cyathus pallidus - 1, KKUITN2/KKULN2; 2, KKITN3/KKULN3; A-B, Basidiocarps; C-D, Peridioles; E-F, Basidiospores.

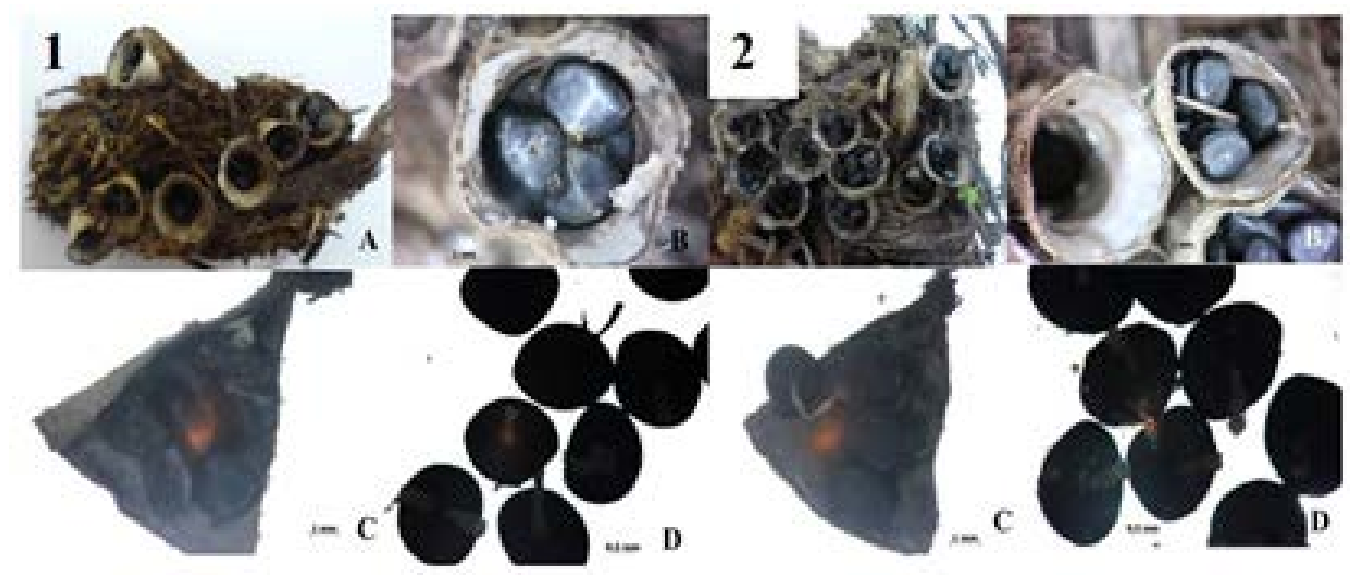

Fig. 4. Cyathus stercoreus - 1, KKUITP2/KKULP2; 2, KKUITP3/ KKULP3; A-B, Basidiocarps; C-D, Peridioles. 
(DQ463336.1) as the Pallidum group. KKULP2 and KKULP3 are closely related to $C$. stercoreus (DQ483338.1) as the Striatum group. Therefore,
KKU1, KKU2, KKU3, KKU4, KKU5, KKU6, KKUNN1 and KKUPR1 are not related to any Cyathus species in this study (Fig. 7).

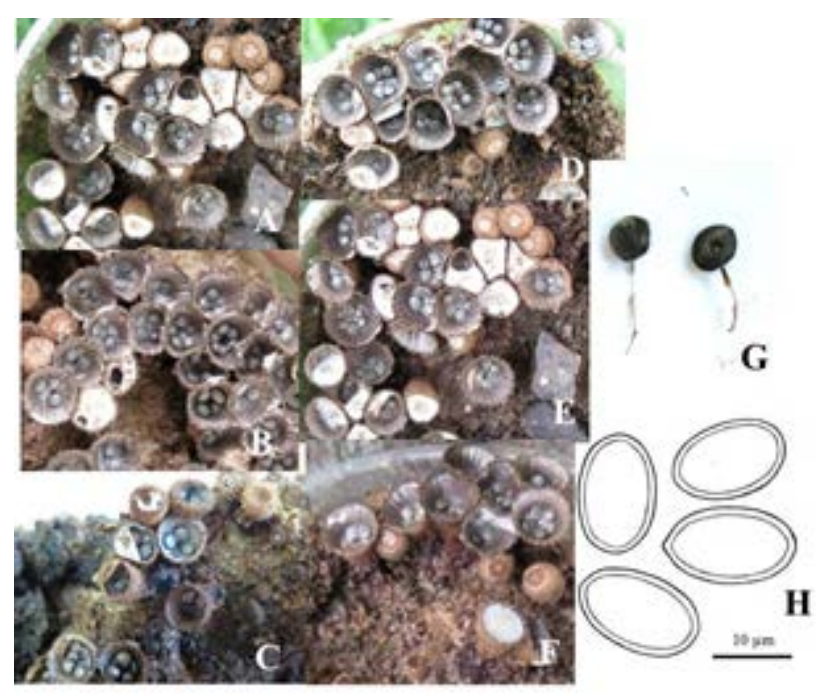

Fig. 5. Cyathus striatus - A-F, Basidiocarp: A, KKU1; B, KKU2; C, KKU3; D, KKU4; E, KKU5; F, KKU6; G, Peridioles; H, Basidiospores.

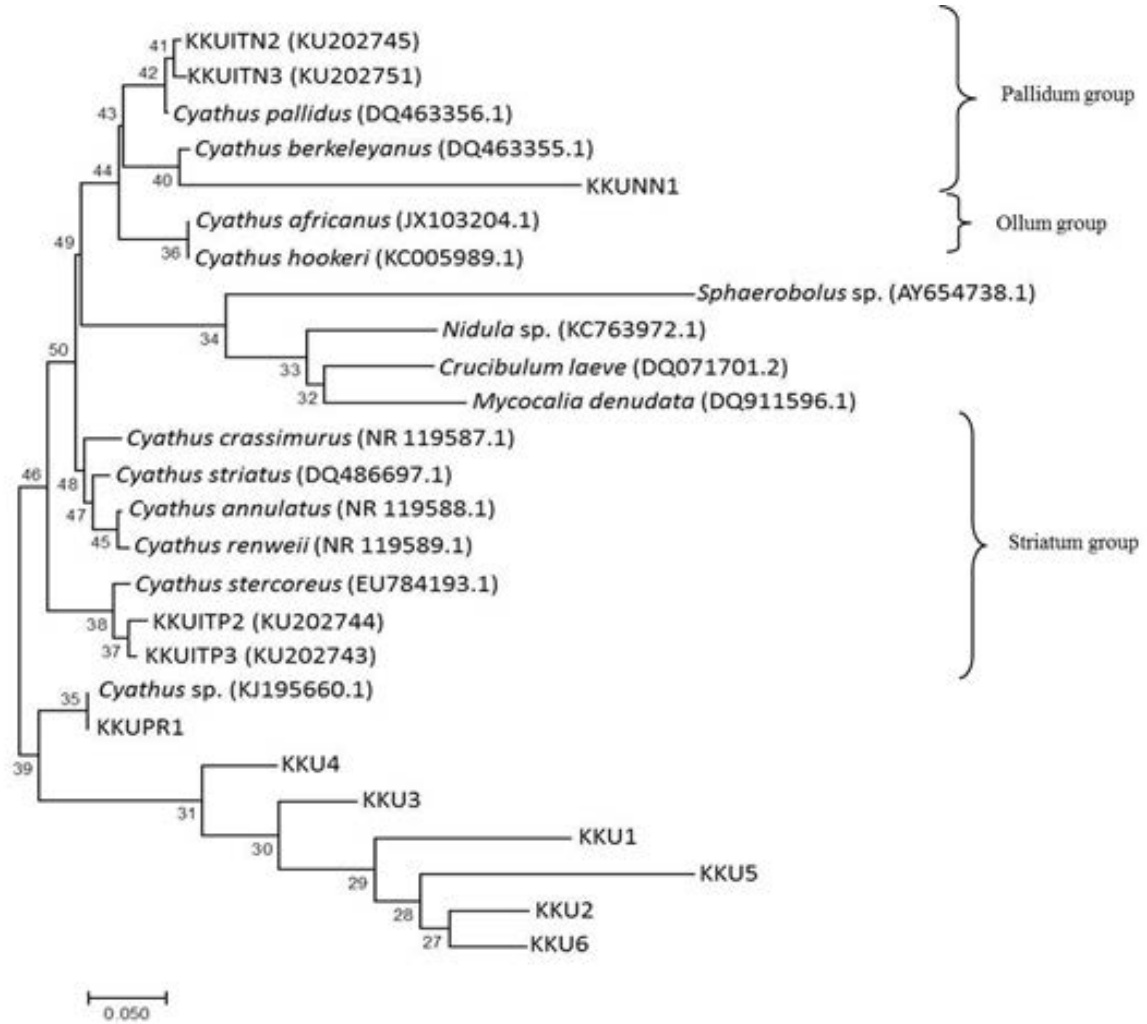

Fig. 6. Phylogenetic relations of Cyathus based on rDNA sequences including ITS-1, $5.8 S$ and ITS-2 regions by neighbor-joining method. Numbers at branches are bootstrap support values based on 1000 replications. 


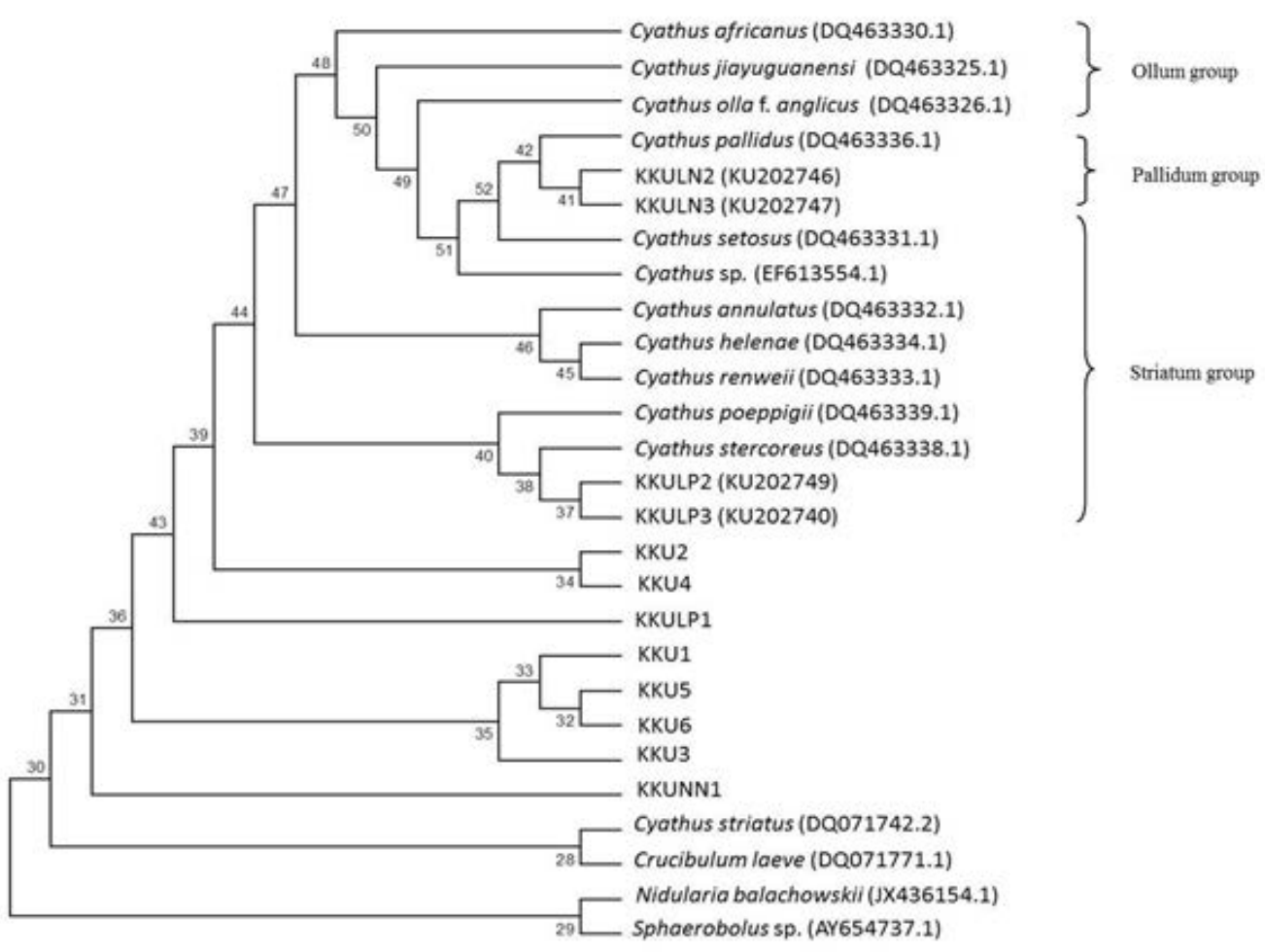

Fig. 7. Phylogenetic relations of Cyathus based on rDNA sequences including LSU regions by neighbor-joining method. Numbers at branches are bootstrap support values based on 1000 replications.

\section{DISCUSSION}

Bird's nest fungi identification is a matter of careful, sometimes microscopic, inspection of the morphological features. In this study we identified Cyathus sp. using morphological characters, including peridiocarp, peridiole and basidiospore, under stereo- and compoundmicroscopes. The results showed that KKUNN1 was C. berkeleyanus; KKUPR1 was C. earlei; KKUITN2 and KKUITN3 were $C$. pallidus; KKUITP2 and KKUITP3 were $C$. stercoreus and KKU1, KKU2, KKU3, KKU4, KKU5 and KKU6 were $C$. striatus. Similarly, Cyathus morelensis with taxonomic opinion, basidiocarp images and peridiole, basidiospores and peridiocarp illustrations. Additionally, the four species that registered from Brazil including C. intermedius, C. montagnei, C. setosus and C. triplex was first reported from northeastern Brazil' ${ }^{2}$. Inspection of holotype of $C$. setosus, found that spore dimensions different from explained in the original publication.
The DNA sequence data of ITS and LSU, were consistent with the morphological identifications of KKUITN2 (C. pallidus), KKUITN3 (C. pallidus), KKUITP2 (C. stercoreus) and KKUITP3 (C. stercoreus). DNA identification may remain undecided if there are insufficient well-identified reference sequences in GenBank and BOLD. For example, BLAST searches in GenBank shown $72-82 \%$ identity with $C$. striatus. In addition, we amplified the SSU sequence of all isolates when compared to the GenBank database it showed that all of them were closely related with $C$. striatus with $99 \%$ identity.

Hence, the DNA data were not informative in this study. Alternately, three infrageneric groups consist of Ollum, Pallidum and Striatum was classified by using datasets of ITS and LSU. Still these three species groups can be separated on morphological basis. In northern Thailand, bird's nest fungi have been collected before and this leaded even to the description of a new 
species, viz.C. subglobisporus ${ }^{22}$. Cyathus olla was keep in culture collections for morphological and molecular studies. First, fruiting body were examined and the results show the much variation between the various collections, and found that classification using morphological characteristics conflicts with current taxonomy feature of species. All field collected accessions basidiocarp were classified by morphology. A new species described as $C$. olla $\mathrm{f}$. brodiensis ${ }^{26}$ distinction from $C$. olla by using morphology and RAPD analysis.

\section{ACKNOWLEDGMENTS}

We are indebted to the Agricultural Research Center for Sustainable Economy, Khon Kaen University and the Center of excellence on Agricultural Biotechnology (AG-BIO/PERDO$\mathrm{CHE}$ ) for the support of research equipment. The authors are grateful to Dr. Jolyon Dodgson for English editing and to Prof. Dr. Thierry Backeljau for correcting the manuscript.

\section{CONFLICT OF INTEREST}

The authors declare that there is no conflict of interest.

\section{AUTHORS' CONTRIBUTION}

Both author(s) have made a substantial, direct and intellectual contribution to the work, and approved it for publication.

\section{FUNDING}

This work was supported by the Holistic Watershed Management Cluster of Khon Kaen University (Grant number NRU57502).

\section{ETHICS STATEMENT}

This article does not contain any studies with human participants or animals performed by any of the authors.

\section{DATA AVAILABILITY}

All datasets generated or analyzed during this study are included in the manuscript.

\section{REFERENCES}

1. Trierveiler-Pereira L, Gomes-Silva AC, Baseia IG. Notes on gasteroid fungi of the Brazilian Amazon rainforest. Mycotaxon. 2009;110:73-80. doi: 10.5248/110.73

2. Trierveiler-Pereira L, Baseia IG. Cyathus species (Basidiomycota: Fungi) from the Atlantic Forest of
Pernambuco, Brazil: taxonomy and ecological notes. Revista Mexicana de Biodiversidad. 2013;84(1):1-6. doi: $10.7550 / \mathrm{rmb} .29868$

3. Kirk PK, Cannon PF, David JC, Stalpers J. Ainsworth \& Bisby's Dictionary of the Fungi," 10 ed., Wallingford, Oxon. $C A B$ international. 2008. doi: 10.1079/9780851998268.0000

4. Hibbett DS, Binder M. Evolution of complex fruiting body morphologies in Homobasidiomycetes. Proceedings of the Royal Society of London B: Biological Sciences. 2002;269(1504):1963-1969. doi: 10.1098/ rspb.2002.2123

5. Brodie HL. The Bird's Nest Fungi. University of Toronto Press, Torronto, Canada, 1975. doi: 10.3138/9781442632516

6. Zhao RL, Desjardin DE, Soytong K, Hyde KD. A new species of bird's nest fungi: characterization of Cyathus subglobisporus sp. nov. based on morphological and molecular data. Persoonia-Molecular Phylogeny and Evolution of Fungi. 2008;21:71-76. doi: 10.3767/003158508X370578

7. Matheny PB, Curtis JM, Hofstetter V, et al. Major clades of Agaricales: a multilocus phylogenetic overview. Mycologia. 2006;98(6):982-995. doi: 10.3852/ mycologia.98.6.982

8. Barbosa MMB, Cruz RHSF, Calonge FD, Baseia IG. Two new records of Cyathus species for South America. Mycosphere. 2014;5(3):425-428. doi: 10.5943/ mycosphere/5/3/5

9. Martin MP, Cruz RHSF, Duenas M, Baseia GI, Telleria MT. Cyathus lignilantanae sp. nov., a new species of bird's nest fungi (Basidiomycota) from Cape Verde Archipelago. Phytotaxa. 2015;236(2):161-172. doi: 10.11646/phytotaxa.236.2.5

10. Accioly T, Cruz RHSF, Assis MN, et al. Amazonian bird's nest fungi (Basidiomycota): Current knowledge and novelties on Cyathus species. Mycoscience. 2017;XX:112.

11. Cruz RHSF, Baseia IG, Hosaka K. Rediscovery of Cyathus badius, an 'extinct' species from the Bonin Islands, Japan. Mycoscience. 2017;xxx:1-7.

12. Zhou TX, Zhao LZ, Zhao RL, Chen YH. Bird's nest fungi from China. Fungal Diversity. 2004;17:243-251.

13. Zang Z, Zhang J, Wang Y, Zheng. Molecular detection of Fusarium oxysporum $f$. sp. niveum and Mycosphaerella melonis in infected plant tissues and soil. FEMS Microbiology Letters. 2005;249(1):39-47. doi: 10.1016/j.femsle.2005.05.057

14. Cruz RHSF, Lima RAA, Braga-Neto R, Baseia IG. Cyathus morekensis, a rare bird's nest fungus in the Brazilian Amazon rainforest. Mycosphere. 2012;3(5):880-882. doi: $10.5943 /$ mycosphere/3/5/13

15. Cruz RHSF, Assis NM, Silva MA, Baseia IG. Revision of the genus Cyathus (Basidiomycota) from the herbaria of northeast Brazil. Mycosphere. 2014;5(4):531-540. doi: $10.5943 /$ mycosphere/5/4/5

16. White TJ, Bruns T, Lee $S$, Taylor JW. Amplification and direct sequencing of fungal ribosomal RNA genes for phylogenetics. In: Innis MA, Gelfand DH, Sninsky JJ, White TJ, (Eds) PCR Protocols: A Guide to Methods and Applications. Academic Press, Inc., New York, 1990:315-322. doi: 10.1016/B978-0-12-372180- 
8.50042-1

17. O'Donnell K. Fusarium and its near relatives. In: Reynolds DR, Taylor JW, (Eds) The Fungal Holomorph: mitotic, meiotic and pleomorphic speciation in fungal systematics Wallingford, CAB International. 1993:225233.

18. Sutthisa $W$, Sanoamuang N. Identification of Pycnoporus coccineus KKUPN1 and effect of colchicine treatment on growth and enzyme production. J P Appl Microbiol. 2017;11(4):1665-1673. doi: 10.22207/ JPAM.11.4.04

19. Sambrook J, Fritsch EF, Maniatis T. Molecular cloning, a laboratory manual. Cold Spring Harbor Laboratory, Cold Spring Harbor, New York, 1989.

20. Thomson JD, Gibson TJ, Plewniak F, Higgins DG. The Clustal-X windows interface: flexible strategies for multiple sequence alignment aided by quality analysis tool. Nucleic Acids Research. 1997;25(24):4876-4882. doi: $10.1093 / \mathrm{nar} / 25.24 .4876$

21. Zhao R-L, Jeewon R, Desjardin DE, Soytong K, Hyde KD. Ribosomal DNA phylogenies of
Cyathus: Is the current infrageneric classification appropriate. Mycologia. 2007;99(3):385-395. doi: 10.1080/15572536.2007.11832563

22. Swofford DL. PAUP*: phylogenetic analysis using parsimony (*and other methods)," Version 4. Sunderland, MA: Sinauer Associates, 1998.

23. Felsenstein J. Confidence limits on phylogenies: An approach using the bootstrap. Evolution. 1985;39(4):783-791. doi: 10.1111/j.1558-5646.1985. tb00420.x

24. HuelsenbeckJP, RonquistF.MRBAYES: Bayesian inference of phylogenetic trees. Bioinformatics. 2001;17(8):754755. doi: $10.1093 /$ bioinformatics/17.8.754

25. Page RDM. TREEVIEW: An application to display phylogenetic trees on personal computers. Computer Applications in the Biosciences. 1996;12:357-358.doi: 10.1093/bioinformatics/12.4.357

26. Shinners TC, Tewari J. Morphological and RAPD analyses of Cyathus olla from crop residue, Mycologia. 1998;90(6):980-989. doi: 10.1080/00275514.1998.12026995 